\title{
UK research councils continue to squabble over biology resources
}

\section{London}

BRITAIN's Science and Engineering Research Council (SERC) has launched a vigorous defence of its role in biological research, raising the temperature of the debate about how best to tackle overlapping interests between the four natural science research councils.

The question about the division of biology between the councils has surfaced during evidence to the House of Lords Select Committee on Science and Technology, which is investigating agriculture and food research in Britain. Conflicting views on the perceived problem of the imperfect distribution of biology resources have prompted the Advisory Board for the Research Councils to set up a committee to examine the present

\section{First victory over tobacco companies}

\section{Washington}

LEGAL history was made last week when, for the first time, a tobacco company was judged partially liable for the death from cancer of a smoker. A federal judge in New Jersey ordered the Liggett Group to pay the widower of Rose Cipollone \$400,000 because, before 1963, the company had advertised its cigarettes as being safe. In one advertising campaign for L\&M cigarettes the company went so far as to declare that its cigarettes were "just what the doctor ordered".

The verdict is not expected to open a floodgate of lawsuits over deaths that may be linked to cigarettes. The jury determined that Cipollone was 80 per cent responsible for her own death. The jury also disagreed with the claim by Antonio Cipollone's lawyers that there was an industry-wide conspiracy to withhold information about the health risks of smoking. Industry lawyers say the relatively small size of the award, and the decision to leave intact the tobacco companies' traditional defence that smokers are responsible for their own actions, will discourage future legal claims.

But consumer activist groups disagree, arguing that much of the legal groundwork in the Cipollone case will make future lawsuits easier to pursue. Many tobacco company documents entered the public domain during the trial, and can be used again. Other documents, not permitted as evidence in this case, may yet surface in other actions. Perhaps even more significantly, the Cipollone decision seems to have encouraged Congress to look more closely at federal regulation of the tobacco industry.

Joseph Palca system and recommend any changes deemed necessary. Of the various options suggested so far, most would result in SERC being deprived of its role in biological research.

That SERC feels under siege is clear, and the council's public relations staff have been working overtime to ensure that its side of the story is heard. SERC's annual expenditure on biology is around $£ 23$ million, which is spent wholly in higher education institutions and which supports around 1,700 research students. In evidence to the Lords' committee two weeks ago, SERC chairman Bill Mitchell made it clear that his council would not relinquish its biology interests without a fight.

The nub of Mitchell's argument is that biology must strengthen its links with the other core sciences and that manpower training is paramount; SERC is best placed to achieve these ends. Mitchell is thus firmly opposed to the establishment of a single non-medical biological research council, an option that has been widely canvassed. Such a move would set an unhealthy precedent for discipline-based research councils, he says.

Mitchell cites SERC's synchroton radiation source at Daresbury as an example of a venture which he suggests "would not have got off the ground so easily" had there been a single biology council. While on the topic of synchrotrons, Mitchell took the opportunity to mention that, despite being asked, the Medical Research Council (which is eyeing SERC's biotechnology) has not made a contribution to the European Synchrotron Radiation Facility at Grenoble, with Britain's contribution being shouldered solely "and with great difficulty" by SERC.

The Royal Society is the latest body to give support to the concept of a nonmedical biology research council, outlined in written evidence to the Lords committee. While advocating that SERC's biology be relinquished to the new council, the society says that "the benefits to biology of direct contacts with the other disciplines [chemistry, physics and engineering], and conversely the benefits to them of links with biology, are substantial and growing, and any new administrative structures would have to ensure these beneficial interactions were maintained and enhanced".

The society, says Mitchell, apparently "wants to have its cake and eat it". The concept is fuzzy and, furthermore, despite being a fellow of the society, he was not shown the evidence before it was submitted.
Simon Hadlington
Successful test firing

\section{Washington}

A two-minute test firing last week of the redesigned solid-fuel booster rocket for the space shuttle seems to have been a success. A final verdict will have to wait until engineers from the National Aeronautics and Space Administration (NASA) and Morton Thiokol disassemble the rocket casing and inspect the segment joints.

One further booster test remains before the shuttle can be declared operational. In that test, now scheduled for the end of July, engineers will introduce deliberate flaws in the rocket joints to determine if their new design will prevent the type of exhaust leak through the O-ring seals that caused the Challenger accident in $\mathbf{1 9 8 6 .}$

The resumption of space shuttle operations is now scheduled for the end of August.

J.P.

\section{Projects for Max Planck Heidelberg}

THE Max Planck Society announced at its annual meeting on 8 June that, given sufficient outside funding, two new projects are ready for approval: an informatics institute in Saarbrücken, and an eight-year project in cognitive anthropology in West Berlin. But funds must be proffered by the Saarland and West Berlin before the projects can begin. Spokesman Michael Globig said the society would try to arrange this support before the 10 November meeting of the Max Planck Society senate, which could then officially establish the two projects.

At the same time, president Heinz Staab announced that the society will establish a research group for retrovirology in Göttingen. The group will carry out three projects related to AIDS research in collaboration with the German Primate Centre.

S.D.

\section{New Soviet telescope}

London

THE world's largest millimetre-band radio telescope is now under construction on the Suffa plateau in Uzbekistan, Izvestiya reported on 31 May. Quoting V. Shlykh, section head at the Space Research Institute of the Soviet Academy of Sciences, the paper said that the 70-m Suffa telescope will work in conjunction with an orbiting radio telescope to study astronomical objects and to determine with a high degree of accuracy the Earth's continental drift and the position of the poles. It will also be used for collaborative studies with the two other large radio telescopes in this wave-band the $30-\mathrm{m}$ radio telescope at Pico Veleta (Spain) and the $45-\mathrm{m}$ instrument at Nobeyama (Japan). The most remarkable feature of the Suffa facility, Izvestiya said, will be the high accuracy of the main dish, which, it is estimated, will deviate from true parabolic form by not more than $0.07 \mathrm{~mm}$.

V.R. 